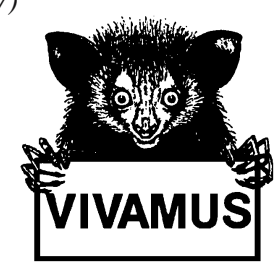

\title{
Behavior, Ecology, and Conservation of Colobine Monkeys: An Introduction
}

\author{
Peter J. Fashing ${ }^{1,2,3,4}$
}

Received July 27, 2006; accepted July 30, 2006; Published Online April 21, 2007

The Colobinae of Africa and Asia are perhaps best known for their specialized stomachs, which allow them to subsist on leafier and more chemically defended diets than most other primates (Kay and Davies, 1994; Oates et al., 1994). Many colobines are also renowned for their shy and indolent dispositions (Fashing, 2006), traits that make them particularly challenging study subjects. Nevertheless, research on colobines has led to some of the most exciting and contentious discoveries in the history of primate behavior and ecology.

Over the past 3 decades, colobines have been at the center of an ongoing debate about the adaptive function of infant killing by males. After repeatedly witnessing male Hanuman langurs (Semnopithecus entellus) attempting to kill unrelated infants on Mount Abu, India in the early 1970s, Hrdy $(1974,1977)$ proposed the groundbreaking hypothesis that infanticide was part of a sexually selected alternative male reproductive strategy. In addition to inspiring a legion of impassioned detractors (Bartlett et al., 1993; Curtin and Dolhinow, 1979), Hrdy's hypothesis stimulated a large body of research not only on primates, but also on other animals, from burying beetles to barn swallows to lions (van Schaik and Janson, 2000). Though the issue of infanticide's adaptive function for male primates remains far from resolved today, at present the strongest evidence consistent with the

\footnotetext{
${ }^{1}$ Department of Science and Conservation, Pittsburgh Zoo and PPG Aquarium, One Wild Place, Pittsburgh, Pennsylvania 15206.

${ }^{2}$ Department of Biological Sciences, Carnegie Mellon University, Pittsburgh, Pennsylvania 15206.

${ }^{3}$ Department of Anthropology, University of Pittsburgh, Pittsburgh, Pennsylvania 15206.

${ }^{4}$ To whom correspondence should be addressed; e-mail: peterfashing@gmail.com.
} 
sexual selection hypothesis has come from studies on the very same colobine species that first inspired Hrdy to develop her hypothesis, Hanuman langurs (Borries et al., 1999, a,b).

In addition to their influential contributions to our understanding of male reproductive strategies, colobines have played an important role in efforts to answer one of the fundamental questions in ecology: what are the ecological determinants of animal abundance? Influenced by earlier theoretical work by Janzen (1974) on the factors affecting vegetation quality in tropical forests, McKey $(1978,1979)$ examined the extent to which the chemical composition of plant items influenced food choice by black colobus (Colobus satanas) at Doula-Edéa, Cameroon. The results of this study led McKey (1978) to suggest that colobine abundance is limited by the quality of the mature foliage available at a site. Although McKey $(1978,1979)$ overestimated the importance of plant chemical defenses on the palatability of leaves to colobines, the results of many subsequent studies have supported his important general notion that leaf quality influences colobine abundance (Chapman et al., 2002; Oates et al., 1990; Waterman et al., 1988). In fact, colobine research over the past few decades has established such a tight predictive relationship between mature leaf quality and colobine biomass across forests (Davies, 1994; Fashing et al., 2007) that it represents one of the strongest examples yet known in the animal kingdom of a single ecological variable influencing animal biomass.

While the contributions of colobine biologists to the fields of primate behavior and ecology have been considerable, colobine researchers have perhaps been even more vital to the development of the relatively new field of primate conservation. Some of the earliest articles on primate conservation were written by the colobine specialists Struhsaker $(1972,1981)$ and Oates $(1977,1979,1981)$, who, in addition to being influential primate ecologists, are leading conservationists today (Oates, 1996a, 1999; Struhsaker, 1997; Struhsaker et al., 2005). Working extensively in rain forests across Africa, Struhsaker, Oates, and colleagues documented the adverse effects of logging, hunting, and other destructive human activities on colobines and other sympatric primates (Oates, 1996b, 1999; Struhsaker, 1997). They also recently had the unfortunate task of having to report the near extinction of Miss Waldron's red colobus (Piliocolobus badius waldronae), the first primate taxon to essentially disappear in ca. $500 \mathrm{yr}$ (Oates et al., 2000; McGraw, 2005). Oates (1996b) contends that among the primates, colobines such as Piliocolobus badius waldronae are unusually vulnerable to extirpation and extinction via hunting because of their inopportune combination of large body size, sluggishness, and often low levels of visual 
alertness. Indeed, though they account for only $15 \%$ of living primate species (Cowlishaw and Dunbar, 2000), 9 (36\%) colobines are on the 2004-06 list of the world's 25 most endangered primates (Mittermeier et al., 2005).

Considering the conservation threats facing colobines, the increased research attention given the subfamily in recent years is encouraging. In fact, there are more colobine studies ongoing today than ever before, with data on issues relating to colobine behavior, ecology, and conservation accumulating at an unprecedented pace (Fashing, 2006; Kirkpatrick, 2006). Seeking to convene as many colobine biologists as possible to present their latest research findings and exchange ideas for future research and conservation priorities, I organized an all-day symposium entitled Behavior, Ecology, and Conservation of Colobine Monkeys that was held at the XXth Congress of the International Primatological Society meetings in Torino, Italy on August 27, 2004. After the Congress, 8 participants submitted manuscripts based on their talks to the International Journal of Primatology; they appear here in revised form as the first 8 articles in this issue. The Editor-in-Chief of the International Journal of Primatology later added 3 additional independently contributed papers consistent with the theme of the issue.

This collection represents a series of primarily natural history-based field studies, several of them employing tools that are relatively new to colobine biology such as GIS (geographic information systems) and computer modeling. It is also clear from this issue that researchers have not applied recent technological innovations in noninvasive hormone monitoring (Lasley and Savage, 2006) and molecular genetics (Di Fiore and Gagneux, 2006) as widely to the colobines as they have to many other primates. While these techniques promise to help answer longstanding questions and open up new avenues for research in colobine biology, the value of observational, question-driven natural history studies such as the ones featured in this issue should not be forgotten. Even with the recent upsurge in research on colobines, it is alarming that many of the world's endangered colobines have never been the subject of even 1 basic ecological study. Many managers are thus faced with the difficult task of planning for the conservation of colobine species whose basic needs they know very little about. It is a sad irony that at a time when the distributions of primate taxa are shrinking worldwide, and population surveys and natural history data are needed more than ever to facilitate informed conservation planning and management, there is increasingly little funding available for this type of basic research. 


\section{ACKNOWLEDGMENTS}

I thank Bill Langbauer and Barbara Baker of the Pittsburgh Zoo for providing me with the encouragement and funding necessary to organize and attend the colobine symposium in Torino. I also thank Cristina Giacoma and her co-organizers of the IPS meetings for their favorable response to my symposium proposal and for providing an excellent venue for the symposium. In addition, I thank Russell Tuttle for encouraging me to organize this colobine special issue and for his guidance and help throughout the production process. Lastly, I thank the participants in the symposium and contributors to this issue for sharing their knowledge about and enthusiasm for colobines.

\section{REFERENCES}

Bartlett, T. Q., Sussman, R. W., and Cheverud, J. M. (1993). Infant killing in primates: A review of observed cases with specific reference to the sexual selection hypothesis. Am. Anthropol. 95: 958-990.

Borries, C., Launhardt, K., Epplen, C., Epplen, J. T., and Winkler, P. (1999a). DNA analyses support the hypothesis that infanticide is adaptive in langur monkeys. Proc. Roy. Soc. Lond. B (Biol. Sci.) 266: 901-904.

Borries, C., Launhardt, K., Epplen, C., Epplen, J. T., and Winkler, P. (1999b). Males as infant protectors in Hanuman langurs (Presbytis entellus) living in multimale groups: Defence pattern, paternity and sexual behaviour. Behav. Ecol. Sociobiol. 46: 350-356.

Chapman, C. A., Chapman, L. J., Bjorndal, K. A., and Onderdonk, D. A. (2002). Application of protein-to-fiber ratios to predict colobine abundance on different spatial scales. Int. J. Primatol. 23: 283-310.

Cowlishaw, G. C., and Dunbar, R. I. M. (2000). Primate Conservation Biology. Chicago University Press, Chicago.

Curtin, R. A., and Dolhinow, P. J. (1979). Infanticide among langurs: A solution to overcrowding. Science Today 13: 35-41.

Davies, A. G. (1994). Colobine populations. In Davies, A. G., and Oates, J. F. (eds.), Colobine Monkeys: Their Ecology, Behaviour and Evolution. Cambridge University Press, Cambridge, UK, pp. 285-310.

Di Fiore, A., and Gagneux, P. (2006). Molecular primatology. In Campbell, C. J., Fuentes, A., MacKinnon, K. C., Panger, M., and Bearder, S. K. (eds.), Primates in Perspective. Oxford University Press, New York, pp. 369-393.

Fashing, P. J. (2006). African colobine monkeys: Patterns of between-group interaction. In Campbell, C. J., Fuentes, A., MacKinnon, K. C., Panger, M., and Bearder, S. K. (eds.), Primates in Perspective. Oxford University Press, Oxford, pp. 201-224.

Fashing, P. J., Dierenfeld, E. D., and Mowry, C. B. (2007). Influence of plant and soil chemistry on food selection, ranging patterns, and biomass of Colobus guereza in Kakamega Forest, Kenya. Int. J. Primatol 27, this issue, DOI: 10.1007/s10764-006-9096-2.

Hrdy, S. B. (1974). Male-male competition and infanticide among langurs (Presbytis entellus) of Abu, Rajasthan. Folia Primatol. 22: 19-58.

Hrdy, S. B. (1977). The Langurs of Abu: Female and Male Strategies of Reproduction. Harvard University Press, Cambridge, MA.

Janzen, D. H. (1974). Tropical blackwater rivers, animals, and mast fruiting by the Dipterocarpaceae. Biotropica 6: 69-103. 
Kay, R. N. B., and Davies, A. G. (1994). Digestive physiology. In Davies, A. G., and Oates, J. F. (eds.), Colobine Monkeys: Their Ecology, Behaviour, and Evolution. Cambridge University Press, Cambridge, UK, pp. 229-249.

Kirkpatrick, R. C. (2006). The Asian colobines: Diversity among leaf-eating monkeys. In Campbell, C. J., Fuentes, A., MacKinnon, K. C., Panger, M., and Bearder, S. K. (eds.), Primates in Perspective. Oxford University Press, Oxford, pp. 186-200.

Lasley, B. L., and Savage, A. (2006). Advances in the understanding of primate reproductive endocrinology. In Campbell, C. J., Fuentes, A., MacKinnon, K. C., Panger, M., and Bearder, S. K. (eds.), Primates in Perspective. Oxford University Press, New York, pp. 356-369.

McGraw, W. S. (2005). Update on the search for Miss Waldron's red colobus monkey. Int. J. Primatol. 26: 605-619.

McKey, D. (1978). Soils, vegetation and seed-eating by black colobus monkeys. In Montgomery, G. G. (ed.), The Ecology of Arboreal Folivores. Smithsonian Press, Washington, DC, pp. 423-437.

McKey, D. B. (1979). Plant Chemical Defenses and the Feeding and Ranging Behavior of Colobus Monkeys in African Rainforests. Ph.D. Dissertation, University of Michigan, Ann Arbor, MI.

Mittermeier, R. A., Valladares-Padua, C., Rylands, A. B., Eudey, A. A., Butynski, T. M., Ganzhorn, J. U., Kormos, R., Aguiar, J. M., and Walker, S. (2005). Primates in Peril: The World's 25 Most Endangered Primates 2004-2006. Conservation International, Washington, DC.

Oates, J. F. (1977). The guereza and man. In Rainier III, Prince, Bourne, G. H. (eds.), Primate Conservation. Academic Press, London, pp. 419-467.

Oates, J. F. (1979). Comments on the geographical distribution and status of the South Indian black leaf-monkey (Presbytis johnii). Mammalia 43: 485-493.

Oates, J. F. (1996a). African Primates Status Survey and Conservation Action Plan. IUCN/SSC Primate Specialist Group, Gland, Switzerland.

Oates, J. F. (1996b). Habitat alteration, hunting and the conservation of folivorous primates in African forests. Austral. J. Ecol. 21:1-9.

Oates, J. F. (1999). Myth and Reality in the Rain Forest: How Conservation Strategies Are Failing in West Africa. University of California Press, Berkeley, CA.

Oates, J. F., Abedi-Lartey, M., McGraw, W. S., Struhsaker, T. T., and Whitesides, G. H. (2000). Extinction of a West African red colobus monkey. Conserv. Biol. 14: 1526-1532.

Oates, J. F., Davies, A. G., and Delson, E. (1994). The diversity of living colobines. In Davies, A. G., and Oates, J. F. (eds.), Colobine Monkeys: Their Ecology, Behaviour and Evolution. Cambridge University Press, Cambridge, UK, pp. 45-73.

Oates, J. F., Whitesides, G. H., Davies, A. G., Waterman, P. G., Green, S. M., Dasilva, G. L., Mole, S. (1990). Determinants of variation in tropical forest primate biomass: New evidence from West Africa. Ecology 71: 328-343.

Struhsaker, T. T. (1972). Rain-forest conservation in Africa. Primates 13: 103-109.

Struhsaker, T. T. (1981). Forest and primate conservation in East Africa. Afr. J. Ecol. 19: 99114.

Struhsaker, T. T. (1997). Ecology of an African Rain Forest: Logging in Kibale and the Conflict Between Conservation and Exploitation. University of Florida Press, Gainesville.

Struhsaker, T. T., Struhsaker, P. J., and Siex, K. S. (2005). Conserving Africa's rain forests: Problems in protected areas and possible solutions. Biol. Conserv. 123: 45-54.

van Schaik, C. P., and Janson, C. H. (2000). Infanticide by Males and Its Implications. Cambridge University Press, Cambridge, UK.

Waterman, P. G., Ross, J. A. M., Bennett, E. L., and Davies, A. G. (1988). A comparison of the floristics and leaf chemistry of the tree flora in two Malaysian rain forests and the influence of leaf chemistry on populations of colobine monkeys in the Old World. Biol. J. Linnean Soc. 34: 1-32. 